\title{
Changes in the transmission of monetary policy: Evidence from the Euro area and the U.S.
}

\author{
Jose Olmo* University of Southampton \\ Marcos Sanso-Navarro, Universidad de Zaragoza
}

May 2014

\begin{abstract}
This paper deals with changes in the monetary policy transmission mechanism derived from appealing to 'unconventional' measures. We propose a bank-based theoretical model for the credit market that establishes the equilibrium relationships between monetary aggregates, interest rates and real income. These relationships are empirically analyzed applying cointegration techniques to macroeconomic data of the Euro area and the United States. Our results provide evidence of a structural break around the collapse of Lehman Brothers in both economies.
\end{abstract}

Keywords: Equilibrium model, 'Unconventional' monetary policies, Transmission mechanisms, Regime change, VECM.

JEL codes: C32, E32, E41, E51.

${ }^{*}$ Corresponding author. Address: School of Social Sciences, Economics Department, University of Southampton, Room 3015, Bld 58 (Murray Bld), Highfield Campus, Southampton, SO17 1BJ, UK. Email: J.B.Olmo@soton.ac.uk. Tel: +44(0)23 8059 2537. Fax: +44(0)23 80593858 . Financial support from Ministerio de Economía y Competitividad (ECO2011-22650 project) and the Regional Government of Aragón (ADETRE Research Group) is gratefully acknowledged. 


\section{Introduction}

Recent years have witnessed a renewed interest in monitoring both monetary and credit developments and implementing 'unconventional' monetary policies (UMPs, hereafter). Across central banks, the approaches adopted have been different and customized to their corresponding economies and structures (Trichet, 2013). These alternative measures have been put into place for two main reasons (International Monetary Fund, 2013). First, nominal short-term interest rates reached the lower bound during this period in many countries, losing their ability to stimulate the economy (Reifschneider and Williams, 2000). In this context, alternative monetary policy instruments include the monetary base (Krugman, 1998), long-term interest rates (McGough et al., 2005) and the exchange rate (Svensson, 2001). Second, disruptions in the financial system generated large losses and affected the liquidity and solvency of both banks and borrowers.

In order to stimulate the economy and recover the effectiveness of 'conventional' monetary policies, central banks have tried to affect interest rates other than the official ones using the size and structure of their balance sheets. Most of these measures have been interpreted as 'unconventional' forms of conducting monetary policy. One noteworthy example is the Maturity Extension Program created by the Federal Reserve (FED) and consisting of sterilized operations by buying long-term government bonds and, simultaneously, selling some of the short-term dated issues. The FED also followed a large-scale asset purchase (LSAP) program of mortgage-backed securities with the aim of increasing market liquidity and reducing mortgage interest rates ('credit easing'). The most popular LSAP across monetary authorities in the recent crisis has been the creation of money to buy assets ('quantitative easing', QE). While the FED bought Treasury, agency debt and agency-backed mortgage securities, the Bank of England purchased government bonds from the non-bank private sector. These measures were aimed at affecting yields in assets and, thereby, restoring liquidity in the financial system. The European Central Bank (ECB) used a different approach to QE for mitigating liquidity problems. It carried out repurchase agreements providing 
long-term loans in exchange for bank loans and non-government bonds as collateral.

The aim of this paper is to analyze the existence of changes in the monetary policy transmission mechanism due to the implementation of these UMPs. We focus on the nonneoclassical credit view of monetary policy transmission. According to this view, banks play a special role in the financial system by resolving asymmetric information problems in credit markets. To investigate the presence of structural breaks in the relationships between macroeconomic and monetary variables due to UMPs, we first develop an extension of the bank-based model for the credit market proposed by Bofinger and Debes (2010). The theoretical model proposed in this paper establishes the equilibrium relationships between the different macroeconomic variables involved in the bank credit channel, namely, the money stock, the official interest rate set by monetary authorities, the credit interest rate and real output. In contrast to Bofinger and Debes (2010), our theoretical model assumes that banks maximize the discounted value of expected profits over an infinite number of future periods. Furthermore, we generalize their theoretical setting by accommodating the existence of more than one type of creditor borrowing from banks. Each creditor type represents a group of investors with the same level of credit riskiness and that, hence, borrow from banks at the same credit interest rate.

In this model, the effect of UMPs corresponds to changes in the parameters driving the equilibrium relationships between the money stock, interest rates and real output. Thus, and as a second contribution of this paper, we propose an empirical model that captures the features of the theoretical model and is consistent with the statistical properties - such as nonstationarity and the presence of stochastic trends - of the variables of interest. A natural candidate in this setting is a Vector Error Correction Model (VECM), which is applied to assess the long-run cointegration relationships between interest rates (official, credit and government debt), monetary aggregates (money stock and monetary base) and real income in the Euro area and the United States (U.S.). We formalize the existence of different regimes, and determine their timing by statistically testing for the presence of a structural break in the residuals of the VECM. For both monetary areas, our empirical 
analysis, given by the implementation of Chow type tests and the study of the stability of the model parameters across the sample, suggests the existence of two regimes.

The statistical evidence of a rejection of the null hypothesis of parameter stability in the VECM model is maximized around the collapse of Lehman Brothers. Given the prominence of this episode, we identify this landmark as determining the break date and define the first regime as a 'normal' period lasting until this collapse and the second as a 'distress' episode running up to the beginning of the year 2014. This second period coincides with the implementation of UMPs by the Federal Reserve Board and the ECB, implying that the comparison of the VECM parameters before and after this event can be useful exercises to assess the impact of these 'unconventional' measures on the monetary policy transmission mechanism and the real economy.

The rest of the article is structured as follows. Section 2 develops the theoretical model for the equilibrium in the credit market. Section 3 presents the empirical analysis of the relationships between money supply, interest rates and real output, and Section 4 concludes. Some analytical derivations have been included in a mathematical appendix.

\section{A bank-based model for the credit market}

The money supply process reflects the interface between the central bank and the commercial banks. Central banks or, more generally, monetary authorities are monopolistic suppliers of the monetary base. The creation of the money stock is determined by the interplay between the central bank, commercial banks and the non-bank sector. For simplicity, in what follows, it will be assumed that the supply of money is the supply of loans ${ }^{1}$, abstracting from the role of monetary authority interventions in the foreign sector as a means of creating monetary base.

In period $t$, a commercial bank's balance sheet satisfies that

$$
Q_{B / N B_{t}}^{s}+R_{t}=Q_{C B / B_{t}}+D_{t},
$$

\footnotetext{
${ }^{1}$ Accordingly, the demand for money is equivalent to the demand for loans.
} 
where $Q_{B / N B_{t}}^{s}$ is the quantity of loans to the non-bank sector and $Q_{C B / B_{t}}$ is the amount of credit from the central bank. $D_{t}$ are the deposits made by customers and $R_{t}$ is the level of reserves held in the central bank, such that $R_{t}=R_{t}^{\min }+E R_{t}$. Denoting the minimum reserve ratio as $0<r<1$, we have that $R_{t}^{\min }=r D_{t}$. $E R_{t}$ refers to the level of reserves held in excess.

There is a conventional wisdom in monetary economics according to which the demand for money is a positive function of real income and a negative function of the interest rate; the latter represents the opportunity cost of holding money. In the present context, we consider the existence of different credit interest rates for borrowers with different credit histories and facilities for obtaining credit from the banking system. This borrower heterogeneity and the corresponding existence of more than one credit interest rate offered by banks for their loans entail different loan demand functions from creditor types. A standard way to model these demand functions and, more specifically, the relationship between money demand, real income and interest rates is by means of a linear function, which in our context applies equally to the demand for loans $\left(Q_{B / N B_{j, t}}^{d}\right)$ and the demand for money $\left(M_{j, t}^{d}\right)$ from that market segment:

$$
M_{j, t}^{d}=Q_{B / N B_{j, t}}^{d}=\mu_{j}+\gamma_{j} Y_{t}-\alpha_{j} i_{c, t}^{j},
$$

where $Y_{t}$ is real income and $i_{c, t}^{j}$ is the credit interest rate for creditor type $j$, with $j=1, \ldots, k$. Hence, $k$ is the number of creditor types. The parameters in expression (2) satisfy that $\mu_{j}>0$ and $\gamma_{j} Y_{t}-\alpha_{j} i_{c, t}^{j} \geq 0$. The aggregate demand for credit is the sum of the demand functions over the set of creditor types. Furthermore, using the above identity between the demand for loans and money, it follows that

$$
M_{t}^{d}=Q_{B / N B_{t}}^{d}=\sum_{j=1}^{k} Q_{B / N B_{j, t}}^{d} .
$$

The demand functions in (2) characterize a market for loans that is completely seg- 
mented by creditor types. Therefore, the demand for credit from a specific type of creditor only depends on the interest rate applied to it and not on the interest rates offered to the other creditor types. Consequently, the different demand functions for loans across markets are only related to each other through real income. It is further assumed that the banking system is made up of $n$ identical banks which act as if they were in the presence of perfect competition, taking the set of loan rates $\left(i_{c, t}^{j}\right)$ as given. For simplicity, and given that our interest lies in studying credit rates, we also take as given the deposit interest rates $i_{d, t}^{l}$, with $l=1, \ldots, k^{*} ; k^{*}$ is the number of saver types ${ }^{2}$. It is also assumed that the official interest rate $\left(i_{r, t}\right)$ and the interest rate paid on excess reserves $\left(\widetilde{i}_{r, t}\right)$ are set by the central bank and exogenous to the bank's optimization problem. In line with Freixas and Rochet (2008), the deposit and the loan market rates will converge to the central bank's official interest rate due to arbitrage opportunities between these markets.

Banks solve an optimization problem that consists of the maximization of the discounted present value of their expected profits over an infinite time horizon:

$$
\max V_{t}=(1-\delta) \sum_{i=0}^{\infty} \delta^{i} E_{t}\left[\Pi_{t+i}\right]
$$

with $\delta \in(0,1)$ being a time preference parameter reflecting banks' views on the importance of future expected profits on their current objective function $V_{t}$. A value of $\delta$ close to zero corresponds to a bank that is only concerned with current profits and disregards the value of future profits in its time $t$ objective function. The profit function at period $t+i$ is

$$
\Pi_{t+i}=\sum_{j=1}^{k} i_{c, t+i}^{j} Q_{B / N B_{j, t+i}}^{s}-i_{r, t+i} Q_{C B / B_{t+i}}+\widetilde{i}_{r, t+i} E R_{t+i}-\sum_{l=1}^{k^{*}} i_{d, t+i}^{l} D_{l, t+i}-F_{t+i},
$$

where $Q_{B / N B_{j, t+i}}^{s}$ is the supply of loans by the bank to creditor type $j$ and $D_{l, t+i}$ the deposits of saver type $l . F_{t+i}$ denotes the amount of troubled assets/defaulted loans generating a cost. Following Cosimano (1988), we assume that this amount depends on macroeconomic

\footnotetext{
${ }^{2}$ As is shown in the mathematical appendix, the existence of different types of savers characterized by different interest rates on their deposits does not influence the equilibrium level of money stock and credit interest rates in this modelling framework.
} 
conditions, proxied by the ratio of credit made available by the bank over real income. In our setting, the relevant penalty function is

$$
F_{t+i}=\frac{\sum_{j=1}^{k} \beta_{j}\left(Q_{B / N B_{j, t+i}}^{s}\right)^{2}}{Y_{t+i}},
$$

where $\beta_{j}$ is a parameter reflecting the relative importance of the defaulted loans corresponding to the creditor type $j$ market in the overall penalty function. This parameter can also be interpreted as the cost of each unit of defaulted loans for the market segment $j$.

In order to be able to determine the solution of the optimization problem, we impose the following dynamic process for the supply of loans by the representative bank in a given segment of the market:

$$
Q_{B / N B_{t+i, j}}^{s}=\rho_{0, j}+\rho_{1, j} Q_{B / N B_{t+i-1, j}}^{s}+\varepsilon_{j, t+i}
$$

with $\rho_{0, j}$ and $\rho_{1, j}$ being the relevant parameters and such that $0 \leq \rho_{1, j} \leq 1 ; \varepsilon_{j, t+i}$ is the error term. In this same line, the ratio $Q_{B / N B_{j, t+i}}^{s} / Y_{t+i}$ is assumed to follow an autoregressive process similar to $(7)$ and to be characterized by the parameters $\widetilde{\rho}_{0, j}$ and $\widetilde{\rho}_{1, j}$, with $0 \leq$ $\widetilde{\rho}_{1, j} \leq 1$. These assumptions guarantee that both the supply of loans and the ratio of loan supply over real income for creditor type $j$ exhibit some persistence over time. The case $\rho_{1, j}=1$ reflects the existence of stochastic trends in the data.

The first order conditions of the maximization problem with respect to the decision variable $Q_{B / N B_{j, t}}^{s}$ yield the following optimal supply of loans to the creditor type $j$ :

$$
Q_{B / N B_{j, t}}^{s *}=\frac{\left(i_{c, t}^{j}-i_{r, t}\right) Y_{t}}{2 \beta_{j}} \Phi_{j}
$$

with $\Phi_{j}=\frac{1-\delta \rho_{1, j} \widetilde{\rho}_{1, j}}{1-\delta \rho_{1, j}}$. The proof of this result is included in the mathematical appendix. Expression (8) can be aggregated over the $n$ identical banks in the system such that the aggregate supply of loans to the creditor type $j$ is $M_{j, t}^{s *}=n Q_{B / N B_{j, t} *}^{s *}$. 
For market segment $j$, the equilibrium loan interest rate is obtained from equalizing aggregate loan supply with aggregate loan demand:

$$
i_{c, t}^{j *}=\frac{2 \beta_{j}\left(\mu_{j}+\gamma_{j} Y_{t}\right)+i_{r, t} n \Phi_{j} Y_{t}}{n \Phi_{j} Y_{t}+2 \alpha_{j} \beta_{j}} .
$$

Expression (9) shows that, in equilibrium, there is a positive relationship between the credit and the official interest rates. Moreover, the cross-section of credit interest rates $i_{c, t}^{j *}$ across creditor types depends on $\alpha_{j}, \mu_{j}$ and $\gamma_{j}$, the parameters that characterize the aggregate demand function; $\rho_{1, j}$ and $\widetilde{\rho}_{1, j}$, that characterize the dynamics in the supply side of the market; and $\beta_{j}$, the unit price of defaulted loans in the loan market segment indexed by $j$. Interestingly, the expression above also shows that the credit interest $i_{c, t}^{j *}$ is closer to the official interest rate set by the central bank as the number of banks competing in this segment of the loan market increases.

The contribution of the amount of loans created in the market for creditor type $j$ to the money stock is given by the equilibrium value $Q_{B / N B_{j, t}}^{*}$. This is obtained by substituting (9) into (2):

$$
M_{j, t}^{*}=Q_{B / N B_{j, t}}^{*}=\frac{\mu_{j}+\gamma_{j} Y_{t}-\alpha_{j} i_{r, t}}{1+2 \alpha_{j} \beta_{j} / n \Phi_{j} Y_{t}} .
$$

This expression establishes the positive relationship between real income and nominal money stock; the official interest rate is, however, negatively related to the money stock in equilibrium. The cost of each unit of defaulted loans, $\beta_{j}$, also plays an important role in the above equilibrium relationships by bringing the value of the model parameters driving the theoretical relationships towards zero. These effects can be better appreciated at the aggregate level, where the stock of money is

$$
M_{t}^{*}=\sum_{j=1}^{k} \frac{\mu_{j}+\gamma_{j} Y_{t}-\alpha_{j} i_{r, t}}{1+2 \alpha_{j} \beta_{j} / n \Phi_{j} Y_{t}} .
$$

The equilibrium expressions (9) and (11) can be simplified if the number of banks $n$ is assumed to be large, as in the limiting case of perfect competition. In this case, the 
equilibrium money stock can be approximated by

$$
M_{t}^{*}=\mu^{*}+\gamma^{*} Y_{t}-\alpha^{*} i_{r, t},
$$

with $\mu^{*}=\sum_{j=1}^{k} \mu_{j}, \gamma^{*}=\sum_{j=1}^{k} \gamma_{j}$ and $\alpha^{*}=\sum_{j=1}^{k} \alpha_{j}$. Similarly, the different credit interest rates converge to the official interest rate $i_{r}$.

These equilibrium relationships are completed by considering the aggregate relationship between the monetary base $B_{t}$ and $i_{r, t}$. It is a stylized fact that the official interest rate moves in the opposite direction to the monetary base put into circulation by the monetary authority. A simple model to quantify this relationship is

$$
B_{t}^{*}=\widetilde{\mu}^{*}-\widetilde{\alpha}^{*} i_{r, t}
$$

with $\widetilde{\mu}^{*}$ and $\widetilde{\alpha}^{*}$ being positive parameters. Thus, the equilibrium relationship between the money stock and the monetary base is obtained by substituting (13) in (11). For example, under perfect competition, we obtain that

$$
M_{t}^{*}=\mu^{*}+\frac{\alpha^{*} \widetilde{\mu}^{*}}{\widetilde{\alpha}^{*}}+\gamma^{*} Y_{t}+\frac{\alpha^{*}}{\widetilde{\alpha}^{*}} B_{t}^{*}
$$

The parameter $\frac{\alpha^{*}}{\widetilde{\alpha}^{*}}$ can be identified with the money multiplier used in monetary economics to measure the money creation process.

Under the assumption that borrowers exhibit a homogeneous demand function across creditor types, the differences in credit interest rates are determined by differences in $\beta_{j}$, higher values of this parameter entailing higher credit interest rates. The dynamics of the banks' loan supply across creditor types, given by $\rho_{1, j}$, also have some influence on the equilibrium expression. Interestingly, if we allow the money demand function (2) to vary across creditor types, the strict monotonicity of the credit interest rate with respect to the level of borrowers' credit risk may be violated due to the existence of non-monotonic differences in the money demand function across creditor types and reflected in the parameter values 
of the money demand function.

The magnitude of $\beta_{j}$ gains importance for moderate values of $n$, characterizing a banking sector that is far from perfectly competitive. In this case, the value of $\beta_{j}$ in the denominator of the expressions above pushes the structural parameters towards zero, establishing a negligible relationship between the money stock, the monetary base and the official interest rate, and creating significant differences between the credit interest rate and the official interest rate, hence implying the failure of the monetary policy transmission mechanism. More specifically, for very large values of $\beta_{j}$, it holds that $M_{t}^{*}=0$ or some positive constant determined outside the model, and $i_{c, t}^{j *}>i_{r, t}$ for all $j=1, \ldots, k$. This effect is exacerbated if the official interest rate approaches zero, when the monetary base also becomes a constant.

These theoretical findings closely correspond to the events that followed the crisis episodes that have taken place worldwide in recent years. In this period, the collapse of major financial institutions prompted an increase in the overall level of risk aversion, taking the form of rises in the amount of defaulted loans and the unit cost of such loans. Banks became more risk averse and, in turn, imposed higher penalties on the possibility of holding defaulted loans in their books. According to the above theoretical model, had monetary authorities and central banks remained inactive in the presence of these events, the consequences of the increase in risk aversion levels would have been reflected in the collapse of the monetary transmission mechanism. Instead, the monetary authorities of the major economies around the world established a variety of unconventional policies with the aim of restoring the monetary and credit transmission mechanisms. Within this framework, Olmo and Sanso-Navarro (2013) propose, in a companion paper, a theoretical model to discuss the implications of the UMPs followed by the U.S. and the Euro area. The aim of the next section is to empirically assess the success of these policies for these two monetary areas. To do this, we analyze the dynamics of the main macroeconomic and monetary variables over the period from January 1998 to February 2014.

In this macroeconomic environment, it is also worth discussing the government interest rate, $i_{g, t}$. During recent years, commercial banks' balance sheets have accumulated sovereign 
debt from distressed economies as a way of obtaining a high return on a relatively safe investment. This fact suggests that governments can be considered as another creditor type because the return on their sovereign debt reflects the degree of credit riskiness and default probability. For this reason, we consider it appropriate to include the government interest rate separately from the other credit interest rates in the empirical analysis carried out in the next section. The credit interest rates considered in the empirical analysis correspond to households and private non-financial corporations. The interest rates for households are further disaggregated into those corresponding to loans and mortgages.

\section{Empirical analysis}

The econometric framework used for modeling the long-run relationships between the variables in our theoretical model is the VECM representation of a multivariate vector autoregression (VAR) for $Z_{t}=\left(\ln M_{t}, i_{c, t}^{j}, i_{g, t}, \ln Y_{t}, \ln B_{t}, i_{r, t}\right)$, under the assumption that these variables are unit root processes with one or more common stochastic trends. This empirical model is given by

$$
\Delta Z_{t}=\mu+A Z_{t-1}+\sum_{j=1}^{p} C_{j} \Delta Z_{t-j}+u_{t}
$$

where $u_{t}$ is a $(6 \mathrm{x} 1)$ unobservable error term, assumed to be a zero-mean independent white noise process with a time-invariant, positive definite covariance matrix $E\left(u_{t} u_{t}^{\prime}\right)=\Sigma_{u}$. The matrix $A$ does not have full rank, implying that it can be decomposed as the product of two $(6 \mathrm{x} r)$ matrices $A=a b^{\prime}$. Further, the rank of this matrix determines the number of cointegration relationships which are defined as $b^{\prime} Z_{t-1} ; a$ and $b$ the loading and cointegration matrices, respectively.

The data analyzed relative to the Euro area has been extracted from the ECB Statistical Data Warehouse. It has a monthly frequency, covers the period from September 2004 to February 2014 and includes the monetary base, working day and seasonally-adjusted M2 as the monetary aggregate and the official interest rate for main refinancing operations. The nominal interest rate for 10-year government bonds has been obtained from a Svensson 
model with continuous compounding and error minimization. Real income has been proxied by the Industrial Production Index, working day and seasonally-adjusted. Three different interest rates for credits have been considered in the empirical analysis. On the one hand, both the interest rates for loans with a maturity up to one year to non-financial corporations and to households (and non-profit institutions serving them). On the other hand, the interest rate applied to lending for house purchases. The evolution of these variables during the sample period is plotted in Figure 1.

\section{[Insert Figure 1 around here]}

The source of information for the U.S. is the FRED economic data of the Federal Reserve Bank of St. Louis. The sample period is January 1998 to December 2013. The monetary base refers to that monitored by the Board of Governors and is not adjusted for changes in reserve requirements. The monetary aggregate is seasonally-adjusted M2 and the official interest rate is the effective one for Federal Funds. Real income is the seasonally-adjusted Industrial Production Index and the corporate credit interest rate is the weighted-average effective loan rate by all commercial banks. The interest rates applied to households are the 24-month finance rate on personal loans at commercial banks and the 30-year conventional mortgage rate. The U.S. government interest rate corresponds to the 10-year constant maturity rate. These variables are represented in Figure 2.

\section{[Insert Figure 2 around here]}

\subsection{Results for the Euro area}

The cointegrated VECM depends on the unit root character of the variables included in the vector $Z_{t}$. Figure 1 shows supporting evidence of this data feature for the different univariate series considered in our analysis for the Euro area. The efficient DF-GLS test proposed by 
Elliot et al. (1996) has been applied to further confirm the I(1) character of these variables. The optimal number of lags has been chosen with the sequential procedure in $\mathrm{Ng}$ and Perron (2001), considering a maximum of twelve. Test statistics corresponding to two alternative specifications of the deterministic component in the regression equation are reported in the left-hand panel of Table 1. With the only exception of the interest rate to household loans, these results confirm our initial suspicion about the unit root non-stationarity of the time series analyzed.

\section{[Insert Tables 1 and 2 around here]}

Although up to twelve endogenous lags $(p)$ have been allowed in the VECM specification, the Hannan-Quinn and Bayesian information criteria suggest including only one (see Table 2) whatever the credit interest rate included in the multivariate system. In light of the unit root test statistics discussed above, the application of Johansen (1991, 1995)'s trace test leads us to establish three cointegration relationships $(r=3)$ among the variables included in $Z_{t}$. Against this background, the estimated cointegration relationships (matrix b) for the Euro area when the corporate credit interest rate is considered are shown in Table 3. The relationships for (the logarithm of) the money stock, the credit interest rate and the government bonds interest rate have been chosen for identification purposes. They correspond to the long-run equilibria in the credit, interest rate and bond markets, respectively.

The results obtained from data covering the full sample period show a weak and mostly insignificant relationship between the variables under study. In the analysis of the corporate credit risk interest rate, we observe that only real income is related to both the money supply and the credit interest rate with the sign consistent with the predictions from economic theory. The third cointegration relationship also uncovers a long-run link between the government and the official interest rates. The sign and magnitude of this relationship reflects a complete pass-through between these interest rates, such that an increase of $1 \%$ 
in the official interest rate corresponds to a similar increase of the government interest rate. These results are consistent across the other two credit interest rates describing the households loan market, see Tables 4 and 5. In this segment, though, the relationship between the credit interest rates and the official interest rate is also statistically significant, indicating some responsiveness of the household loans and mortgages rates to movements of the official rate.

To assess the possibility of a structural break in the VECM, we apply the samplesplit Chow test. The p-values for its bootstrap version (Candelon and Lütkepohl, 2001), corresponding to the period from January 2007 to December 2011, are reported in the upper panel of Figure 3. The null hypothesis of no break is systematically rejected at the 5\% significance level after August 2008, with the test statistic attaining its maximum value in February 2009. This result is robust across the different empirical exercises that are performed in this subsection. We will denote this time interval as the period around the collapse of Lehman Brothers.

\section{[Insert Figure 3 around here]}

Given the evidence of the presence of a structural break, the analysis carried out for the whole sample is repeated for two subperiods covering January 2004 to February 2009 and March 2009 to February 2014, respectively. Proceeding in that way reveals some interesting findings. First, the estimates corresponding to the pre-break period are similar in scope and magnitude to those of the full sample period. The only noteworthy difference is the significance of the parameter associated with the official interest rate in its relationship with the money stock for the first subsample. This result is also observed after the break for the credit interest rate and suggests a negative relationship between the official interest rate and the money stock through the impact of the former variable on the monetary base. Second, and compared to the full sample and first subsample, during the post-break period, the monetary base better describes the long-run relationship between the variables as it 
is statistically significant in most of the cointegration relationships analyzed. Finally, we note that the money stock and real income have a negative relationship across the different credit interest rates. This counterintuitive result highlights the role of the 'unconventional' measures after the break. In contrast to the period before the crisis, the money stock grows during the second subsample as a response to declining values of output in order to stimulate production and economic activity. Further evidence of the importance of UMPs to restore economic activity is the lack of responsiveness of the corporate and household loan interest rates to changes in the official interest rate. The mortgage interest rate, in contrast, remains associated with the official interest rate, although, with a coefficient far from unity. This latter finding reflects the direct relationship between these interest rates through contractual conditions that determine mortgages with floating interest rates and the impact of risk aversion during this period.

\section{[Insert Tables 3 to 6 around here]}

The possible existence of changes in the monetary policy transmission mechanism can also be assessed through the comparison of the impulse-response functions (IRFs), corresponding to the structural version of the reduced form model in (15), for both the preand post-break subperiods. In this structural model, the identification focuses on the errors of the system, interpreted as linear combinations of exogenous shocks (Lütkepohl and Krätzig, 2004). More specifically, the identification has been achieved by imposing the recursive structure implied by the ordering of the variables in $Z_{t}$. Following a triangular orthogonalization, a shock to the official interest rate affects all the other variables in the system; a shock to the monetary base affects all the other variables except the official interest rate; and so forth.

The comparison of the IRFs before and after the break for the case of the Euro area provide further evidence of the existence of two regimes and the effect of UMPs, see Figures 4 and 5. In particular, we observe that the IRFs corresponding to the policy variables 
such as the official interest rate and the monetary base have completely different dynamics before and after the break. This is particularly relevant for the impact of shocks to the monetary base on credit interest rates. The positive or null effect observed before the break date changes after this moment to reflect a declining trend that indicates that monetary base shocks have a negative effect on credit interest rates. Similarly, shocks to the official interest rate have more sustained effects on the corporate credit interest rate in the postbreak period. Interestingly, the IRFs analyzing the impact of the policy variables on real income reveal smaller effects under the implementation of 'unconventional' measures than in the previous period. This result may be indicative of a sluggish response of economic activity to the creation of money under UMPs and the sequence of cuts in interest rates.

\section{[Insert Figures 4 and 5 around here]}

\subsection{U.S. economy}

A similar analysis to that described in the previous subsection has been carried out with data referring to the U.S. economy. The unit root character of the corresponding macroeconomic variables is confirmed both by the time series displayed in Figure 2 and the test statistics in the last two columns of Table 1. For the three credit interest rates considered in our analysis, the information criteria suggest the inclusion of two endogenous lags in the multivariate system (see Table 2). In addition, Johansen's trace test establishes three cointegration relationships among the variables in the VECM. The graph in the lower panel of Figure 3 shows evidence of the existence of a structural break. The supremum of the sequence of sample-split Chow test statistics corresponds to September 2008, and coincides with the collapse of Lehman Brothers.

Table 6 reports the estimates of the VECM corresponding to the corporate credit interest rate. The results are divided into a full sample period and two subsamples determined by the structural break, found in this case for September 2008. As was also the case for the 
Euro area, the official interest rate is not found to be significantly related to the money stock when the structural break is not taken into account. However, both real income and the monetary base are linked to the amount of money and exhibit the expected sign. The official interest rate is statistically significant in the long-run relationships with the corporate credit and government bond interest rates. More interestingly, there is empirical evidence of an almost one-to-one relationship between the official interest rate and the interest rate for corporate credit. The second subsample is characterized by the greater influence of the monetary base on U.S. government bonds interest rates. Surprisingly, during this period, the official interest rate is positively related to the money stock and the corporate credit interest rate long-run relationship breaks down.

\section{[Insert Tables 6 to 8 around here]}

Table 7 reports estimation results for the VECM model including the credit interest rate for household loans. The long-run relationships referring to the full sample period are in line with those described above. The main difference is that the pass-through from the official interest rate to the credit interest rate is of a much smaller magnitude. This result changes sharply when only data from the pre-break period are considered, at which time credit interest rates for households are also more responsive to the evolution of both the real economy and the monetary base. After the break, and although the corresponding estimated parameter is close to one, the official interest rate is not statistically significantly related to the credit interest rate. However, the interest rates charged on household loans are responsive to economic conditions and, more importantly, to the monetary base. Table 8 shows the equilibrium relationships obtained when the mortgage interest rate is considered. These figures suggest that the differences in the estimated relationships between the preand post-break periods mainly affect the magnitude of the estimated parameters and not their sign. Interest rates on household mortgages and government bonds become more responsive to the evolution of the official interest rate. Broadly speaking, only long-term 
interest rates are related to the official interest rate after the break. This finding can be interpreted as evidence of a higher influence of UMPs on longer-term interest rates in the U.S.

\section{[Insert Figures 6 and 7 around here]}

The IRFs plotted in Figure 6 also show that the response to shocks in monetary policy variables changes across subperiods. It can be observed that the money stock in the U.S. is more responsive to monetary policy shocks after the break. Contrary to what happened in the Euro area, corporate interest rates are more affected by shocks to the government bonds interest rate in the second subsample. The IRFs in Figure 7 suggest that, while the interest rate to household loans is more responsive to shocks in the official interest rate

after the break, the interest rate for mortgages is more affected by shocks to the monetary base and long-term interest rates. In addition, and although they are of a lower magnitude with respect to the pre-break period, monetary policy shocks in times of 'unconventional' measures have higher effects on the real economy in this case.

\section{Conclusions}

In the face of severe dislocations in financial markets and profound declines in economic activity, monetary authorities around the globe have taken extraordinary measures to stabilize the economy beyond merely lowering short-term policy rates. The effectiveness of these 'unconventional' measures, which aim to restore the functioning of the financial system, has been the object of debate since their inception.

In this article, we have developed a bank-based model for describing the relationship between the money stock, interest rates and real income in equilibrium. This model highlights the importance of the level of competition in the banking sector. For economies with a highly competitive banking industry, the credit and official interest rates do not deviate 
much and the money stock is positively (negatively) related to real income (the official interest rate). In this framework, the implementation of 'conventional' monetary policies should be sufficient to reduce risk aversion and restore the lending channel from commercial banks to the private sector. Alternatively, departures from perfect competition highlight the role of the cost of defaulted loans on banks' balance sheets. This cost is associated with the borrower credit conditions and overall risk aversion levels. The theoretical model developed in this paper shows that, for high levels of risk aversion, poor borrower credit conditions and low competition in the banking sector, the 'conventional' transmission mechanism from official interest rates to the economy through credit interest rates and the money stock is seriously compromised. The implications of our model motivate the implementation of 'unconventional' monetary measures acting on the monetary base with the aim of reducing risk aversion by improving credit conditions and, hence, restoring the conventional transmission channels of monetary policy.

These implications have been empirically tested with macroeconomic data for the Euro area and the U.S. The results suggest the presence of two regimes in the relationships between monetary variables, interest rates and real income. The break date determining these regimes corresponds to the period around the collapse of Lehman Brothers, a landmark episode that can be broadly identified with the triggering of substantial 'unconventional' monetary policies by central banks. The comparison of the long-run relationships between the variables obtained from different VECM and the corresponding impulse response functions provides empirical evidence of differences in the monetary transmission mechanism before and after the break date. The pre-break period is characterized by the existence of a 'conventional' mechanism to transmit monetary policy that is determined by the connection between the official and credit interest rates. The post-break period is characterized by a more prominent role of the monetary base in describing long-run equilibrium relationships, an overall breakdown of the relationship between credit and official interest rates, and a negative effect between money stock and real income suggesting that, during this period and contrary to economic theory, the money stock increases when real income falls. In this 
environment, money stock grows as a consequence of 'unconventional' programs creating monetary base to purchase assets and provide liquidity to the financial system, and not as a result of economic activity.

\section{References}

[1] Bofinger, P. and S. Debes, 2010. A primer on unconventional monetary policy. CEPR Discussion Paper No. 7755.

[2] Candelon, B. and H. Lütkepohl, 2001. On the reliability of Chow-type tests for parameter constancy in multivariate dynamic models. Economics Letters 73(2), 155-160.

[3] Elliott, G., T. J. Rothenberg and J. H. Stock, 1996. Efficient tests for an autoregressive unit root. Econometrica 64(4), 813-836.

[4] Freixas, X. and J. C. Rochet, 2008. Microeconomics of Banking. MIT Press.

[5] International Monetary Fund, 2013. Unconventional monetary policies - Recent experiences and prospects. IMF Policy Paper, May.

[6] Johansen, S., 1991. Estimation and hypothesis testing of cointegration vectors in gaussian vector autoregression models. Econometrica 59(6), 1551-1580.

[7] Johansen, S., 1995. Likelihood-based inference in cointegrated vector autoregressive models. Oxford University Press.

[8] Krugman, P. R., 1998. It's baaack: Japan's slump and the return of the liquidity trap. Brookings Papers on Economic Activity 49(2), 137-206.

[9] McGough, B., G. D. Rudebusch and J. C. Williams, 2005. Using a long-term interest rate as the monetary policy instrument. Journal of Monetary Economics 52(5), 855-879. 
[10] Ng, S. and P. Perron, 2001. Lag length selection and the construction of unit root tests with good size and power. Econometrica 69(6), 1519-1554.

[11] Olmo, J. and M. Sanso-Navarro, 2013. Unconventional monetary policies and the bank lending channel. Working paper available at SSRN: http://ssrn.com/abstract $=2249915$.

[12] Reifschneider, D. and J. C. Williams, 2000. Three lessons for monetary policy in a low inflation era. Journal of Money, Credit and Banking 32(4), 936-966.

[13] Svensson, L. E. O., 2001. The zero bound in an open-economy: a foolproof way of scaping from a liquidity trap. Monetary and Economic Studies 19(S-1), 277-312.

[14] Trichet, J-C., 2013. Unconventional monetary policy measures: Principles-conditionsraison d'etre. International Journal of Central Banking 9(1), 229-250. 


\section{Mathematical Appendix}

This section details the derivation of the first order conditions of the optimization problem faced by the representative bank in (4) consisting of the maximization of the discounted present value of its profits:

$$
\max V_{t}=(1-\delta) \sum_{i=0}^{\infty} \delta^{i} E_{t}\left[\Pi_{t+i}\right]
$$

The profit function at period $t+i$ is

$$
\Pi_{t+i}=\sum_{j=1}^{k} i_{c, t+i}^{j} Q_{B / N B_{j, t+i}}^{s}-i_{r, t+i} Q_{C B / B_{t+i}}+\widetilde{i}_{r, t+i} E R_{t+i}-\sum_{l=1}^{k^{*}} i_{d, t+i}^{l} D_{l, t+i}-F_{t+i}
$$

By substituting (1) and (6) into the profit function, it can be expressed in terms of $Q_{B / N B_{j, t+i}}^{s}$ as

$$
\begin{aligned}
\Pi_{t+i}= & \sum_{j=1}^{k}\left[\left(i_{c, t+i}^{j}-i_{r, t+i}\right) Q_{B / N B_{j, t+i}}^{s}\right]-i_{r, t+i}\left(R_{t+i}-D_{t+i}\right)+\widetilde{i}_{r, t+i} E R_{t+i}-\sum_{l=1}^{k^{*}}\left[i_{d, t+i}^{l} D_{l, t+i}\right] \\
& -\sum_{j=1}^{k}\left[\frac{\beta_{j}\left(Q_{B / N B_{j, t+i}}^{s}\right)^{2}}{Y_{t+i}}\right]
\end{aligned}
$$

Moreover, the exogeneity of the official interest rate $\left(i_{r}\right)$, the interest rate paid on excess reserves $\left(\widetilde{i}_{r}\right)$, the amount of deposits held in the commercial bank by individuals $\left(D_{l}\right)$ and their corresponding interest rates $\left(i_{d}^{l}\right)$, implies that the first order conditions are

$\frac{\partial V_{t}}{\partial Q_{B / N B_{j, t}}^{s}}=(1-\delta) \sum_{i=0}^{\infty} \delta^{i}\left\{\left(i_{c, t}^{j}-i_{r, t}\right) E_{t}\left[\frac{\partial Q_{B / N B_{j, t+i}}^{s}}{\partial Q_{B / N B_{j, t}}^{s}}-2 \beta_{j} E_{t}\left[\frac{Q_{B / N B_{j, t+i}}^{s}}{Y_{t+i}} \frac{\partial Q_{B / N B_{j, t+i}}^{s}}{\partial Q_{B / N B_{j, t}}^{s}}\right]\right\}=0\right.$

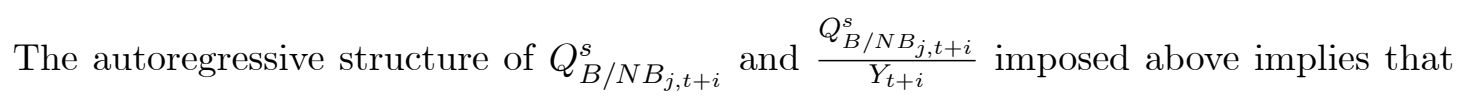


the first order condition corresponding to the decision variable $Q_{B / N B_{t, j}}^{s}$ is

$$
(1-\delta) \sum_{i=0}^{\infty} \delta^{i}\left\{\rho_{1, j}^{i}\left(i_{c, t}^{j}-i_{r, t}\right)-2 \beta_{j} \rho_{1, j}^{i} \widetilde{\rho}_{1, j}^{i} \frac{Q_{B / N B_{j, t}}^{s}}{Y_{t}}\right\}=0
$$

Rearranging terms, we obtain that

$$
(1-\delta)\left(i_{c, t}^{j}-i_{r, t}\right) \sum_{i=0}^{\infty}\left(\delta \rho_{1, j}\right)^{i}-2 \beta_{j}(1-\delta) \frac{Q_{B / N B_{j, t}}^{s}}{Y_{t}} \sum_{i=0}^{\infty}\left(\delta \rho_{1, j} \widetilde{\rho}_{1, j}\right)^{i}=0
$$

Given that each sum converges to a finite value, it follows that

$$
(1-\delta)\left(i_{c, t}^{j}-i_{r, t}\right) \frac{1}{1-\delta \rho_{1, j}}-2 \beta_{j}(1-\delta) \frac{1}{1-\delta \rho_{1, j} \widetilde{\rho}_{1, j}} \frac{Q_{B / N B_{j, t}}^{s}}{Y_{t}}=0
$$

Moving the second part of this expression to the left-hand side, the expression reads as

$$
\left(i_{c, t}^{j}-i_{r, t}\right) \frac{1}{1-\delta \rho_{1, j}}=2 \beta_{j} \frac{1}{1-\delta \rho_{1, j} \widetilde{\rho}_{1, j}} \frac{Q_{B / N B_{j, t}}^{s}}{Y_{t}}
$$

and, hence,

$$
Q_{B / N B_{j, t}}^{s}=\frac{1-\delta \rho_{1, j} \widetilde{\rho}_{1, j}}{1-\delta \rho_{1, j}} \frac{\left(i_{c, t}^{j}-i_{r, t}\right) Y_{t}}{2 \beta_{j}}
$$




\section{Tables and Figures}

Table 1: Unit root testing for the univariate time series.

\begin{tabular}{|c|c|c|c|c|c|c|c|c|}
\hline & \multicolumn{4}{|c|}{ Euro area } & \multicolumn{4}{|c|}{ United States } \\
\hline & \multicolumn{2}{|c|}{ Constant } & \multicolumn{2}{|c|}{ Trend } & \multicolumn{2}{|c|}{ Constant } & \multicolumn{2}{|c|}{ Trend } \\
\hline & lags & DF-GLS & lags & DF-GLS & lags & DF-GLS & lags & DF-GLS \\
\hline$M 2$ & 6 & -0.01 & 6 & -1.22 & 9 & 1.57 & 4 & -1.69 \\
\hline$B$ & 6 & -0.41 & 8 & $-3.32^{* *}$ & 2 & 2.51 & 9 & -1.11 \\
\hline$Y$ & 3 & $-1.82^{*}$ & 3 & -2.10 & 7 & -0.57 & 7 & -2.57 \\
\hline$i_{r}$ & 2 & -1.14 & 2 & -1.67 & 9 & -1.09 & 8 & $-3.72^{* * *}$ \\
\hline$i_{g}$ & 0 & -1.16 & 0 & -1.87 & 5 & -0.40 & 1 & $-3.22^{* *}$ \\
\hline$i_{c}^{\text {corporate }}$ & 4 & -1.48 & 8 & -2.34 & 7 & -1.21 & 7 & $-3.50^{* * *}$ \\
\hline$i_{c}^{\text {households }}$ & 12 & $-2.61^{* * *}$ & 12 & $-3.06^{*}$ & 10 & 0.86 & 10 & $-2.72^{*}$ \\
\hline$i_{c}^{\text {mortgages }}$ & 4 & -1.20 & 3 & -2.69 & 2 & 0.33 & 10 & -2.39 \\
\hline
\end{tabular}

Note: DF-GLS is the unit root test proposed by Elliot et al. (1996). The lag length is determined using the modification of $\mathrm{Ng}$ and Perron (2001) to the Akaike information criterion (MAIC). The maximum number of lags allowed is $12 .{ }^{*},{ }^{* *}$ and ${ }^{* * *}$ denote rejection of the unit root null at the $10 \%, 5 \%$ and $1 \%$ significance levels, respectively. Sample period is 2004:09-2014:12 for the Euro area and 1998:01-2013:12 for the United States. 
Table 2: Cointegration rank testing and lag order determination for the multivariate system.

\begin{tabular}{|c|c|c|c|c|c|c|}
\hline \multirow[b]{3}{*}{ Null hypothesis } & \multicolumn{6}{|c|}{ Euro area } \\
\hline & \multicolumn{2}{|c|}{$i_{c}^{\text {corporate }}$} & \multicolumn{2}{|c|}{$i_{c}^{\text {households }}$} & \multicolumn{2}{|c|}{$i_{c}^{\text {mortgages }}$} \\
\hline & LR & p-value & LR & p-value & LR & p-value \\
\hline $\mathrm{r}=0$ & 389.02 & 0.00 & 353.70 & 0.00 & 374.50 & 0.00 \\
\hline $\mathrm{r}=1$ & 199.48 & 0.00 & 164.37 & 0.00 & 186.24 & 0.00 \\
\hline $\mathrm{r}=2$ & 64.32 & 0.00 & 60.80 & 0.01 & 69.26 & 0.00 \\
\hline $\mathrm{r}=3$ & 26.43 & 0.32 & 32.82 & 0.09 & 36.38 & 0.04 \\
\hline $\mathrm{r}=4$ & 7.91 & 0.83 & 12.24 & 0.44 & 11.26 & 0.53 \\
\hline $\mathrm{r}=5$ & 2.33 & 0.71 & 4.20 & 0.39 & 3.26 & 0.54 \\
\hline Hannan-Quinn & & 1 & & 1 & & 1 \\
\hline Schwarz & & 1 & & 1 & & 1 \\
\hline
\end{tabular}

\begin{tabular}{|c|c|c|c|c|c|c|}
\hline \multirow[b]{3}{*}{ Null hypothesis } & \multicolumn{6}{|c|}{ United States } \\
\hline & \multicolumn{2}{|c|}{$i_{c}^{\text {corporate }}$} & \multicolumn{2}{|c|}{$i_{c}^{\text {households }}$} & \multicolumn{2}{|c|}{$i_{c}^{\text {mortgages }}$} \\
\hline & $\mathrm{LR}$ & p-value & $\mathrm{LR}$ & p-value & $\mathrm{LR}$ & $\mathrm{p}$-value \\
\hline $\mathrm{r}=0$ & 512.53 & 0.00 & 329.95 & 0.00 & 404.11 & 0.00 \\
\hline $\mathrm{r}=1$ & 262.35 & 0.00 & 93.73 & 0.00 & 163.22 & 0.00 \\
\hline $\mathrm{r}=2$ & 51.66 & 0.08 & 43.16 & 0.33 & 52.77 & 0.06 \\
\hline $\mathrm{r}=3$ & 25.05 & 0.40 & 20.17 & 0.72 & 20.39 & 0.70 \\
\hline $\mathrm{r}=4$ & 9.02 & 0.74 & 7.97 & 0.82 & 6.50 & 0.92 \\
\hline $\mathrm{r}=5$ & 3.30 & 0.54 & 2.86 & 0.61 & 2.98 & 0.59 \\
\hline Hannan-Quinn & \multicolumn{2}{|c|}{2} & \multicolumn{2}{|c|}{2} & \multicolumn{2}{|c|}{2} \\
\hline Schwarz & \multicolumn{2}{|c|}{2} & \multicolumn{2}{|c|}{2} & \multicolumn{2}{|c|}{2} \\
\hline
\end{tabular}

Note: LR is the trace test proposed by Johansen (1995). The deterministic term is an intercept. The maximum number of lags allowed is 12. Sample period is 2004:09-2014:02 for the Euro area and 1998:01-2013:12 for the United States. 


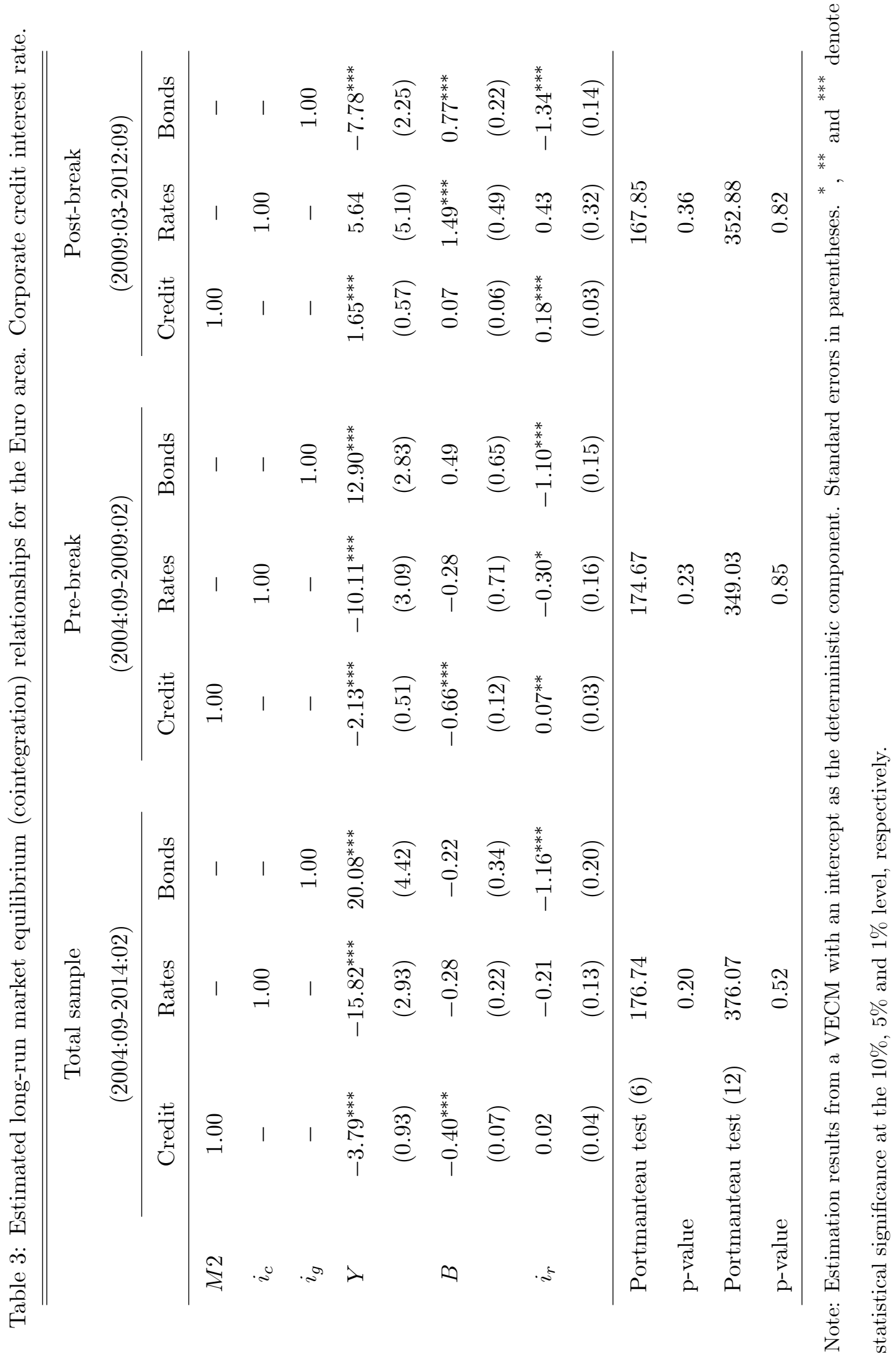




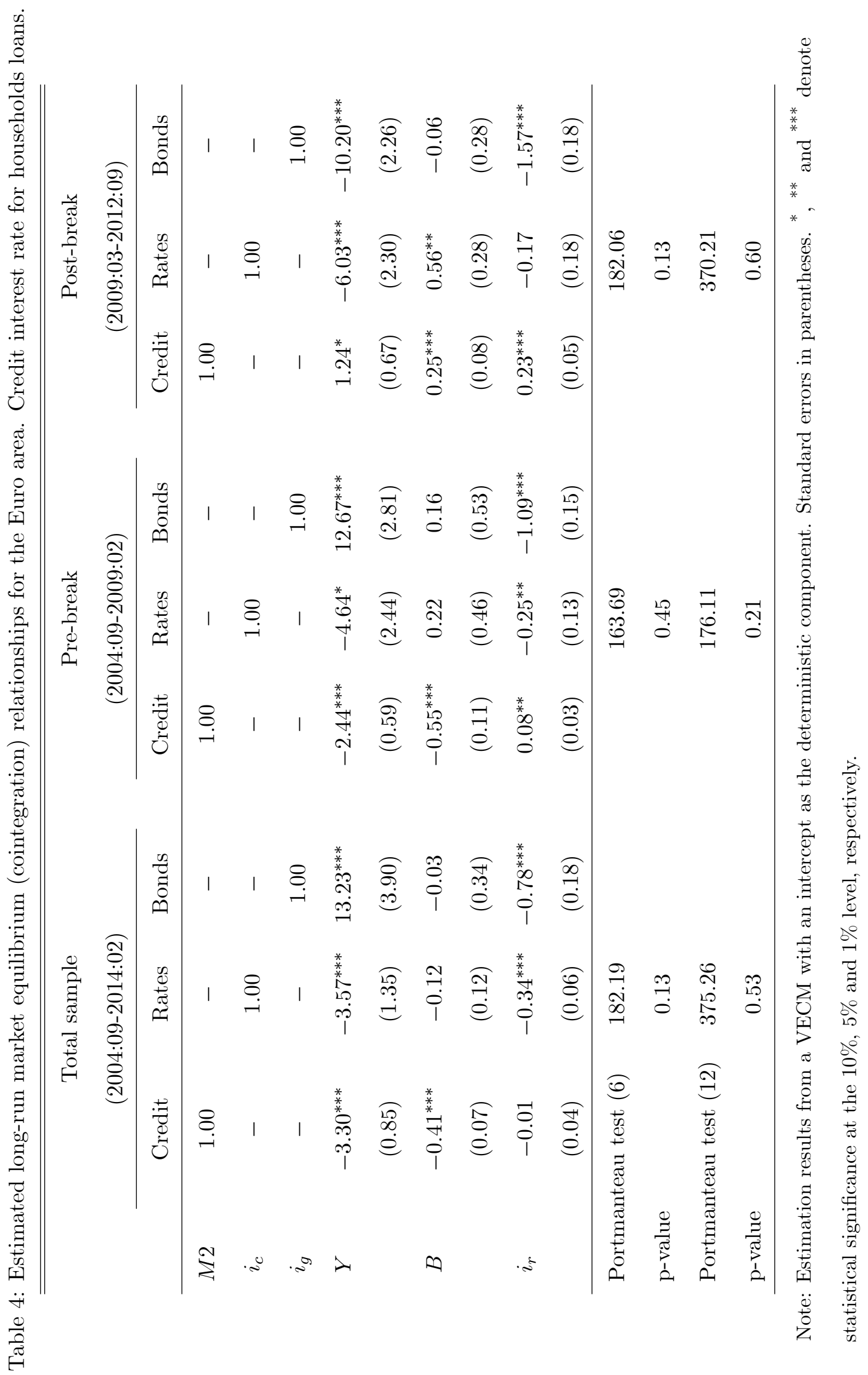




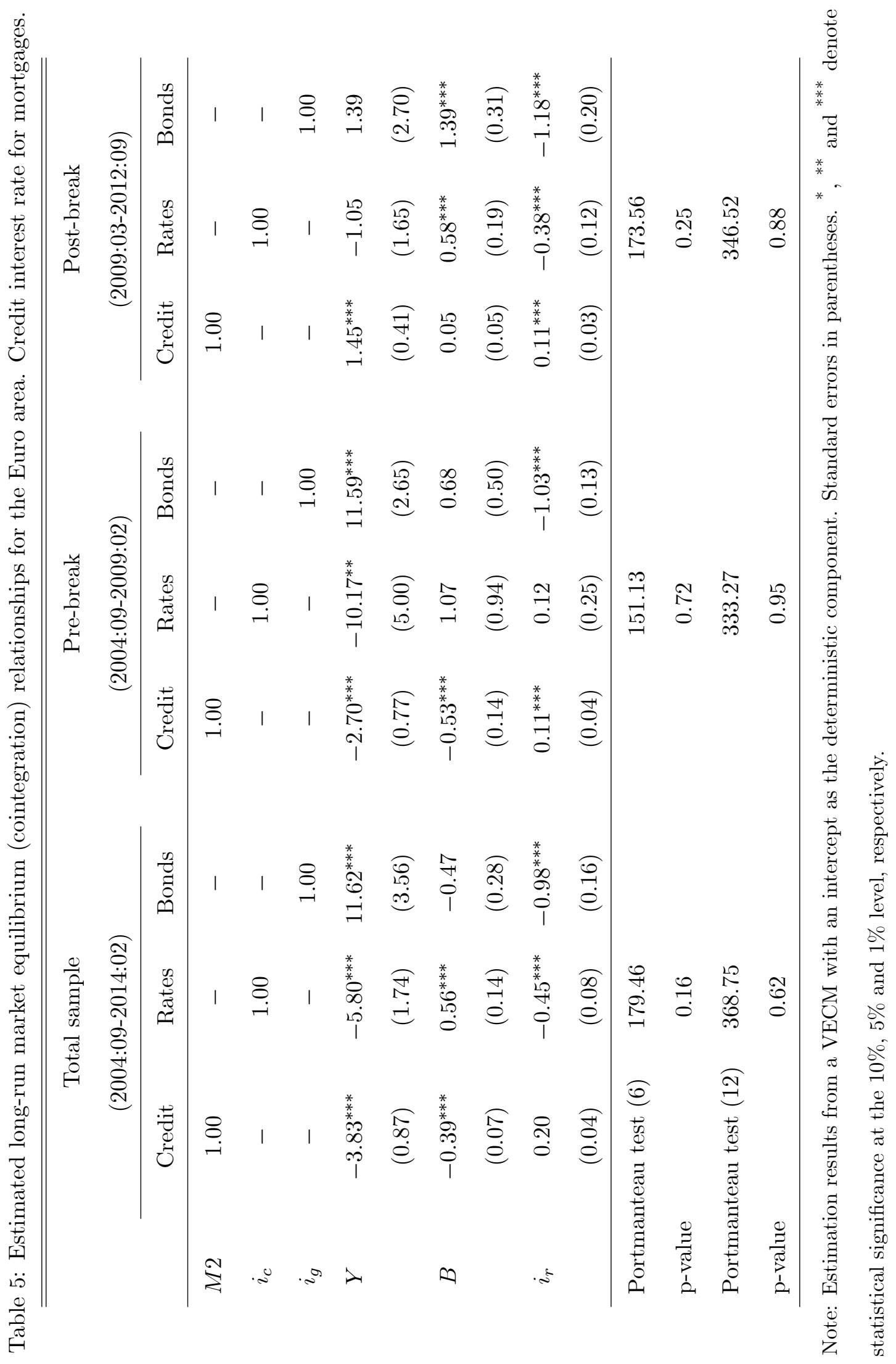




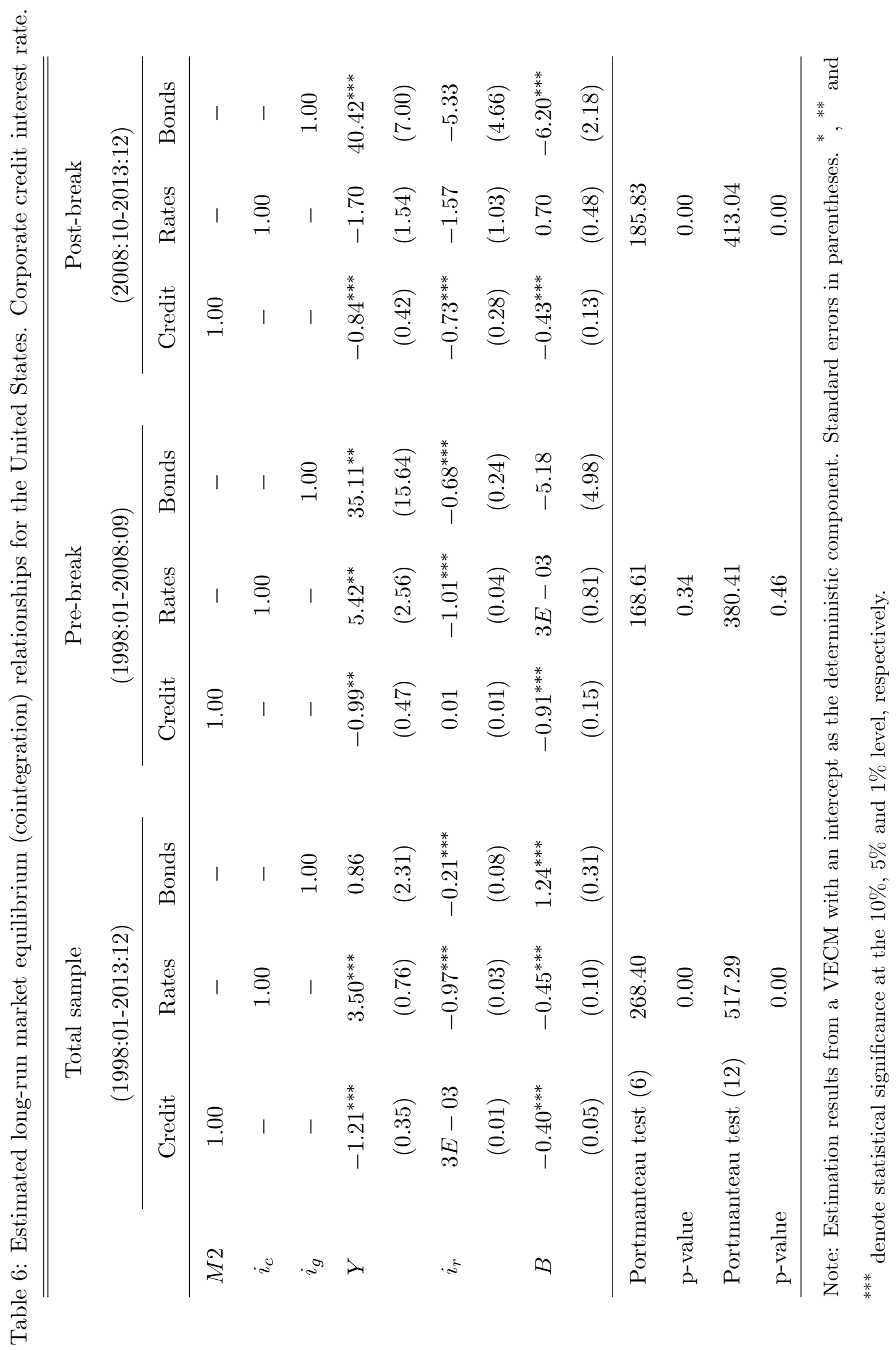




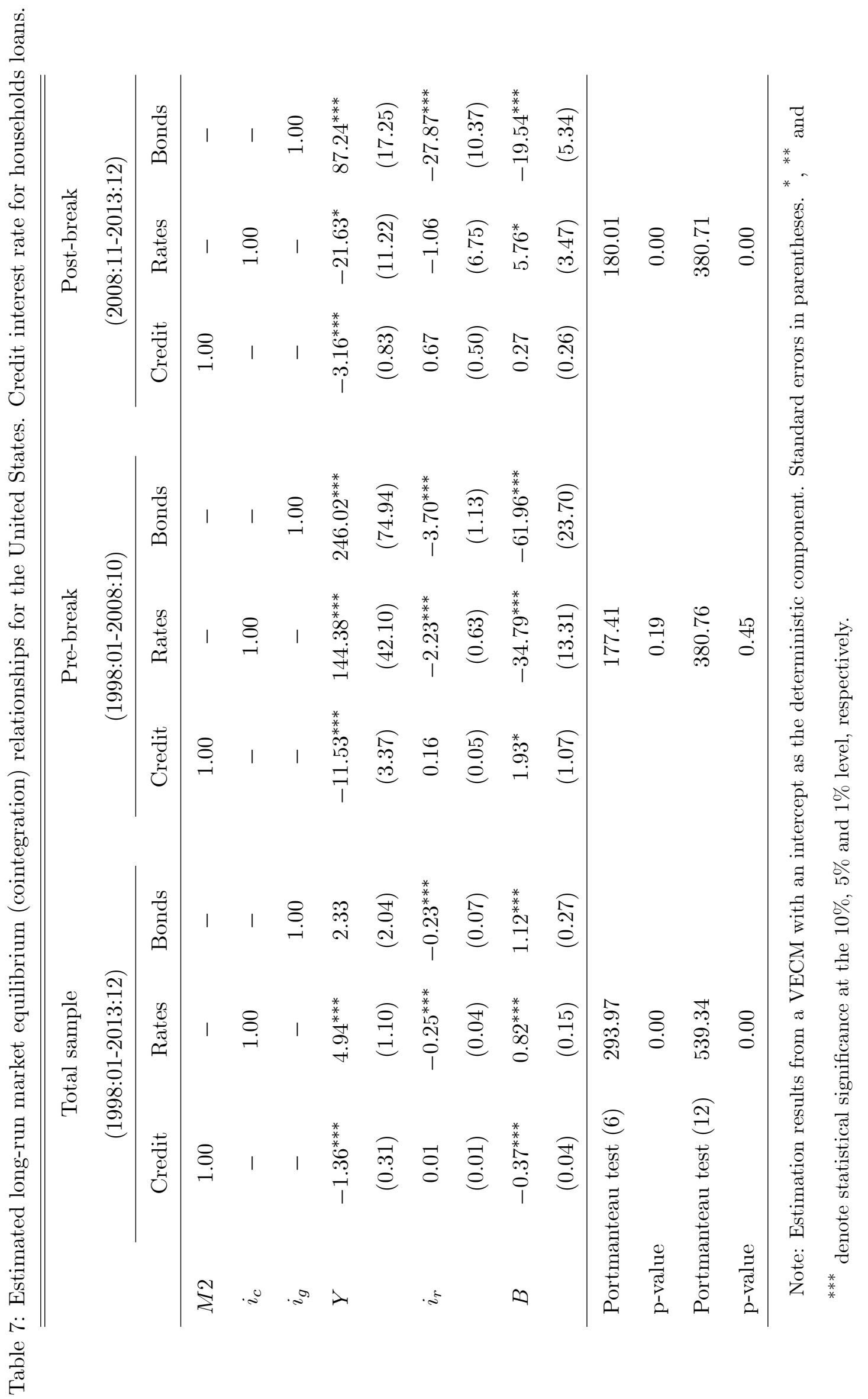




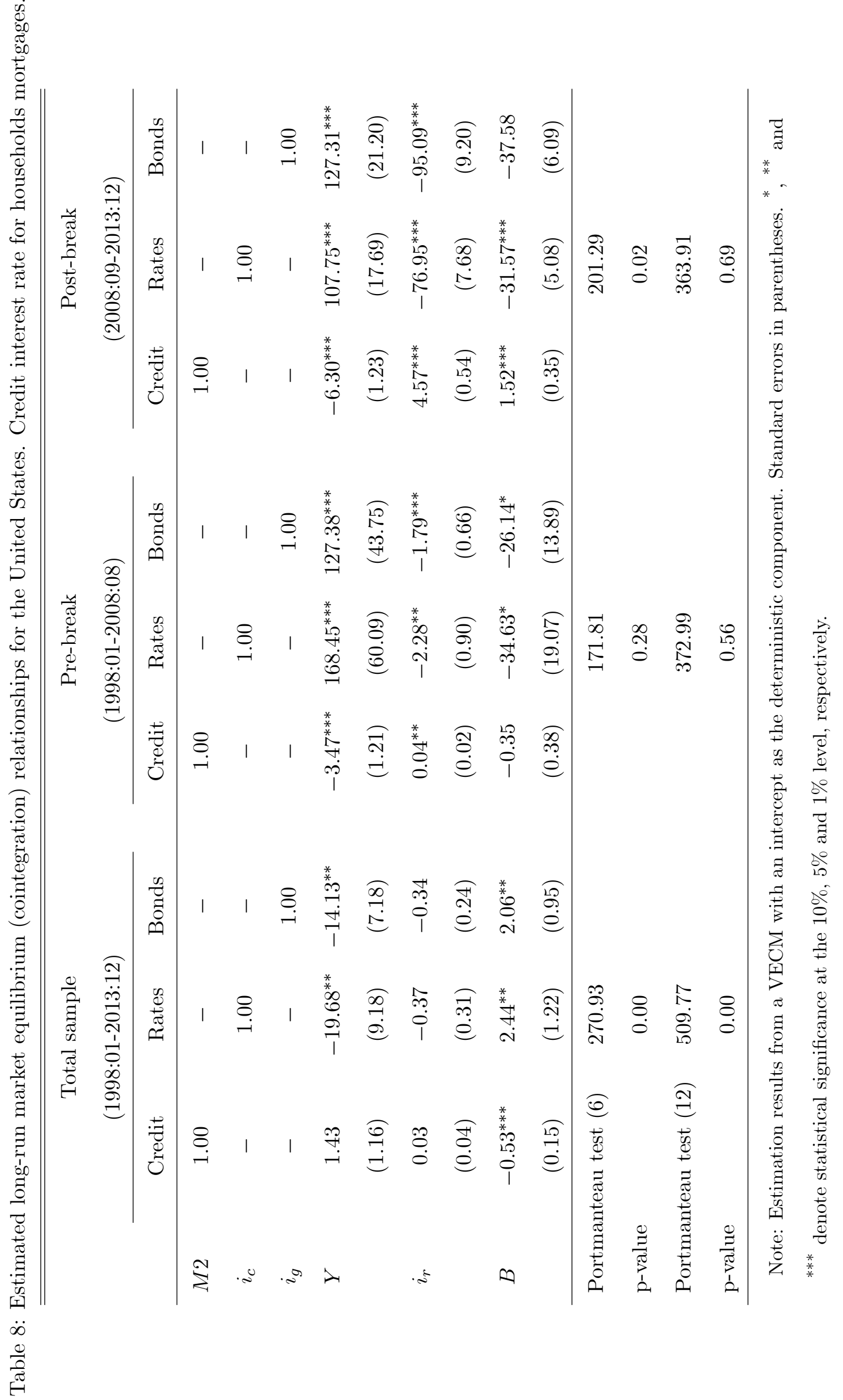


M2 (logs)

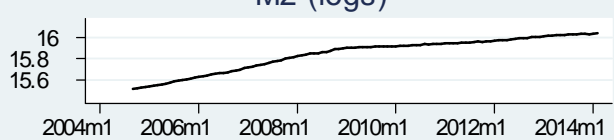

Y (logs)

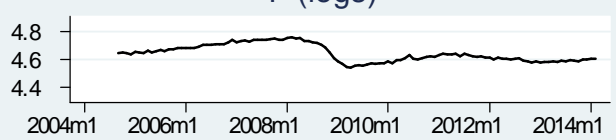

ig

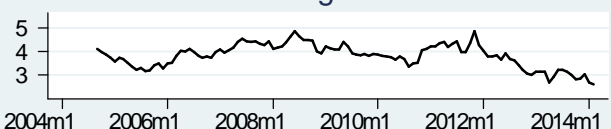

ic_households

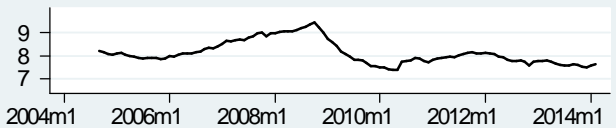

B (logs)

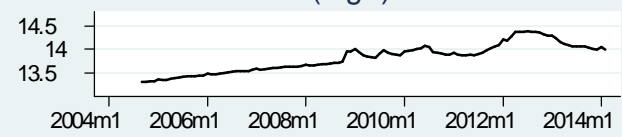

ir

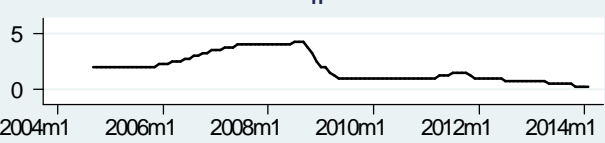

ic_corporate

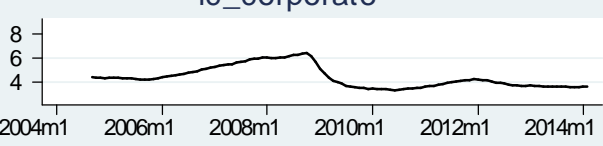

ic_mortgages

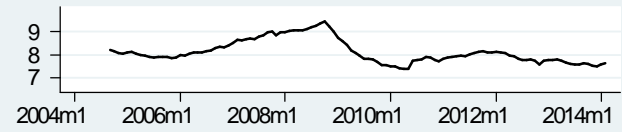

Figure 1: Macroeconomic and monetary variables for the Euro area, 2004:09-2014:02. 

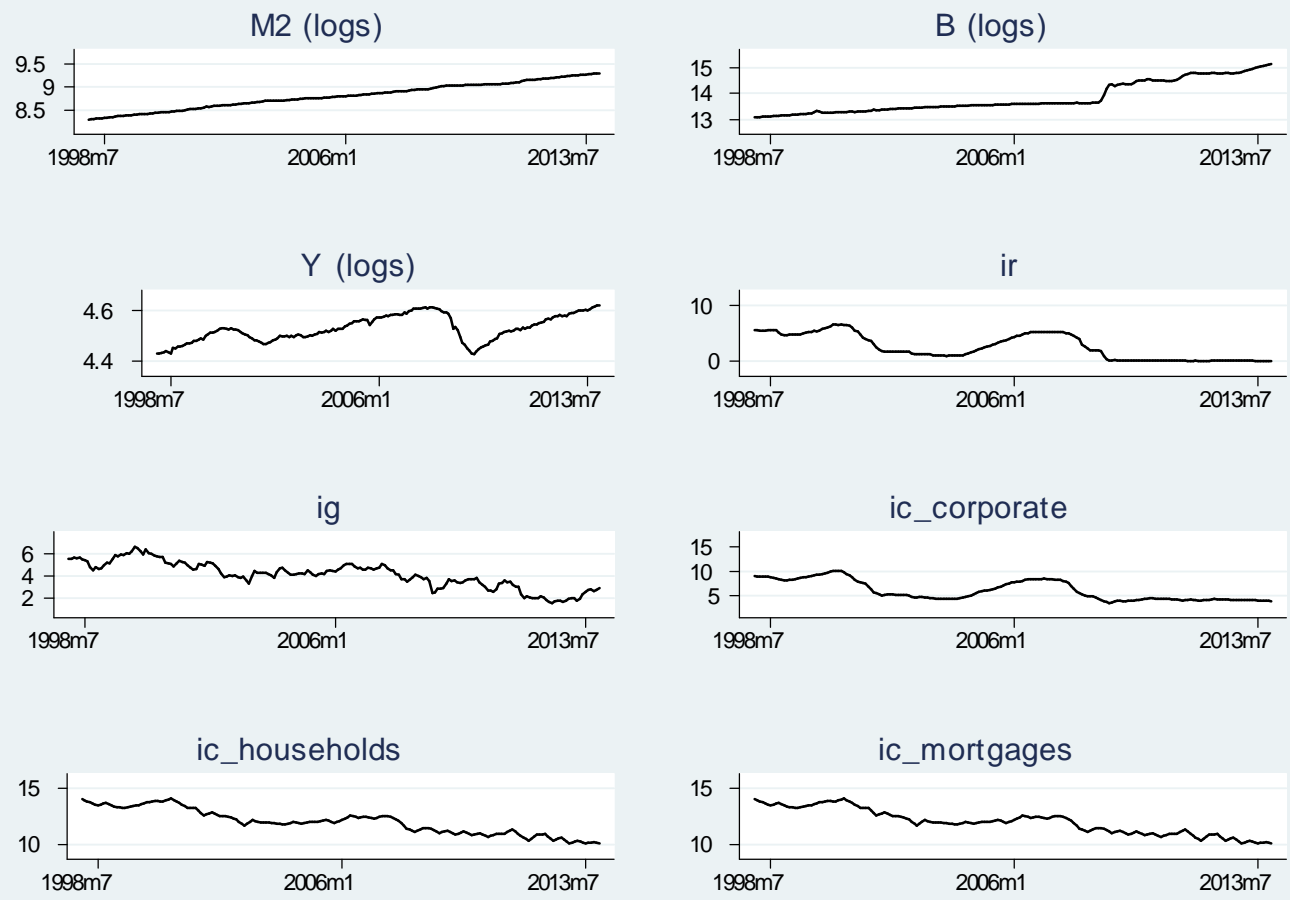

Figure 2: Macroeconomic and monetary variables for the United States, 2004:09-2012:09. 


\section{Euro area}

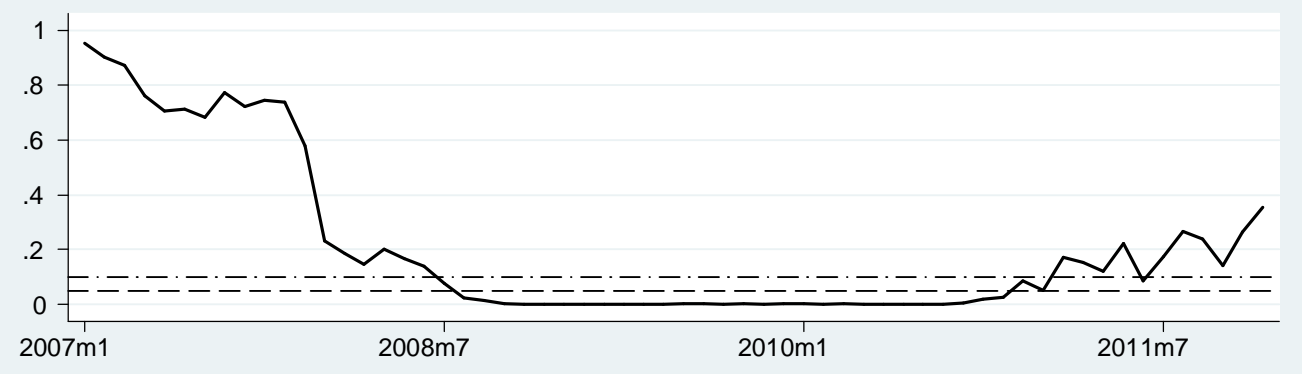

United States

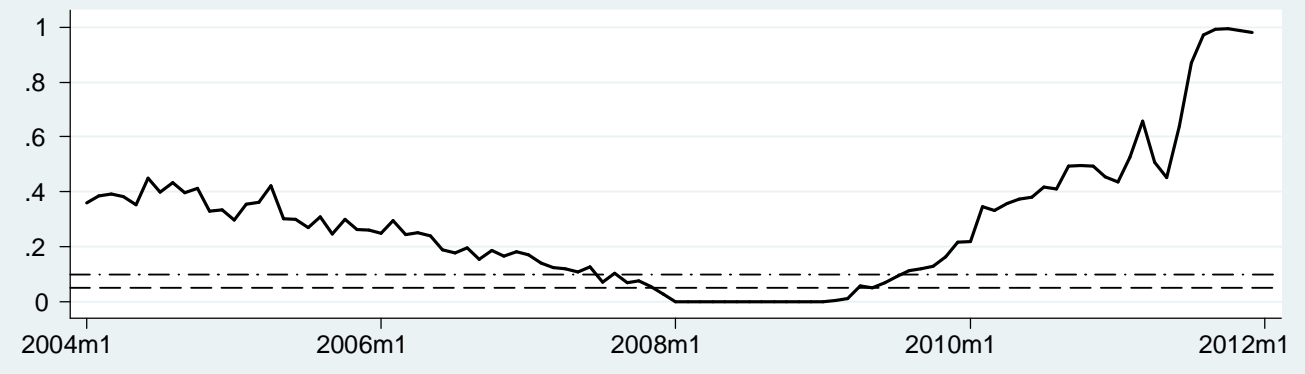

Figure 3: VECM estimation with the corporate credit interest rates. Bootstrap p-values (500 replications) for the sample-split Chow test. 

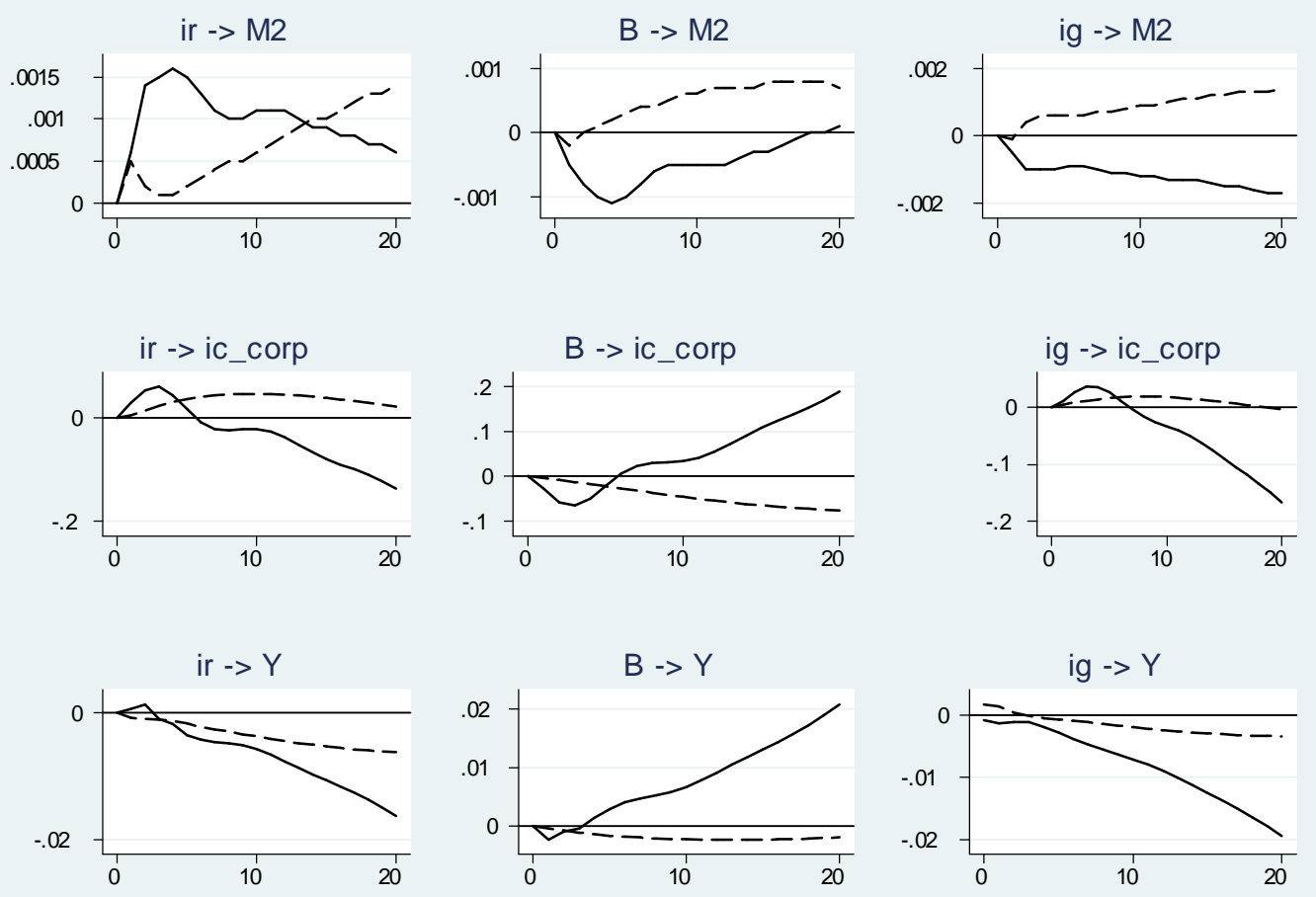

Figure 4: Impulse response functions for the Euro area. Corporate credit interest rate. Before (solid) and after (dashed) the break. 

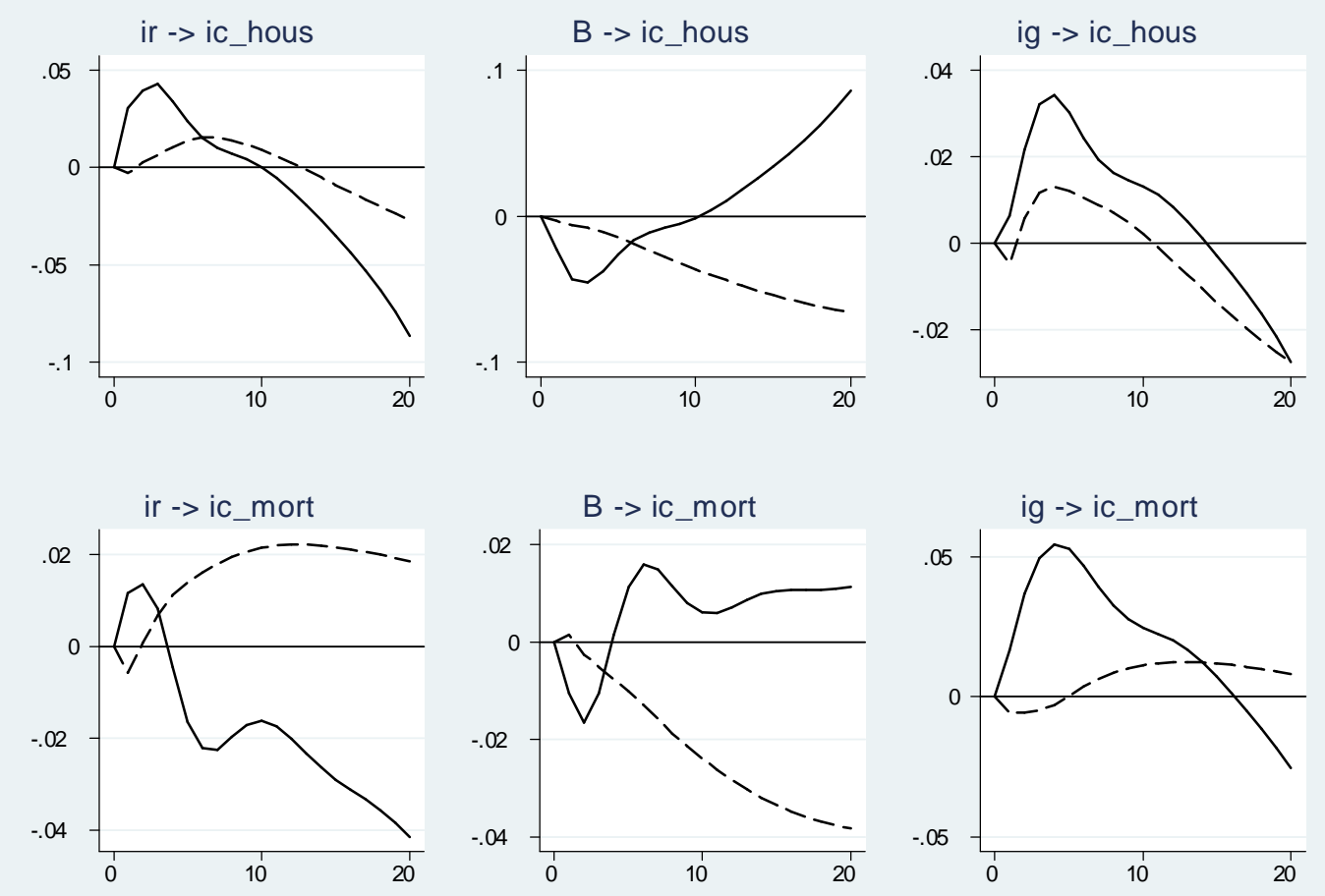

Figure 5: Impulse response functions for the Euro area. Credit interest rates to households. Before (solid) and after (dashed) the break. 

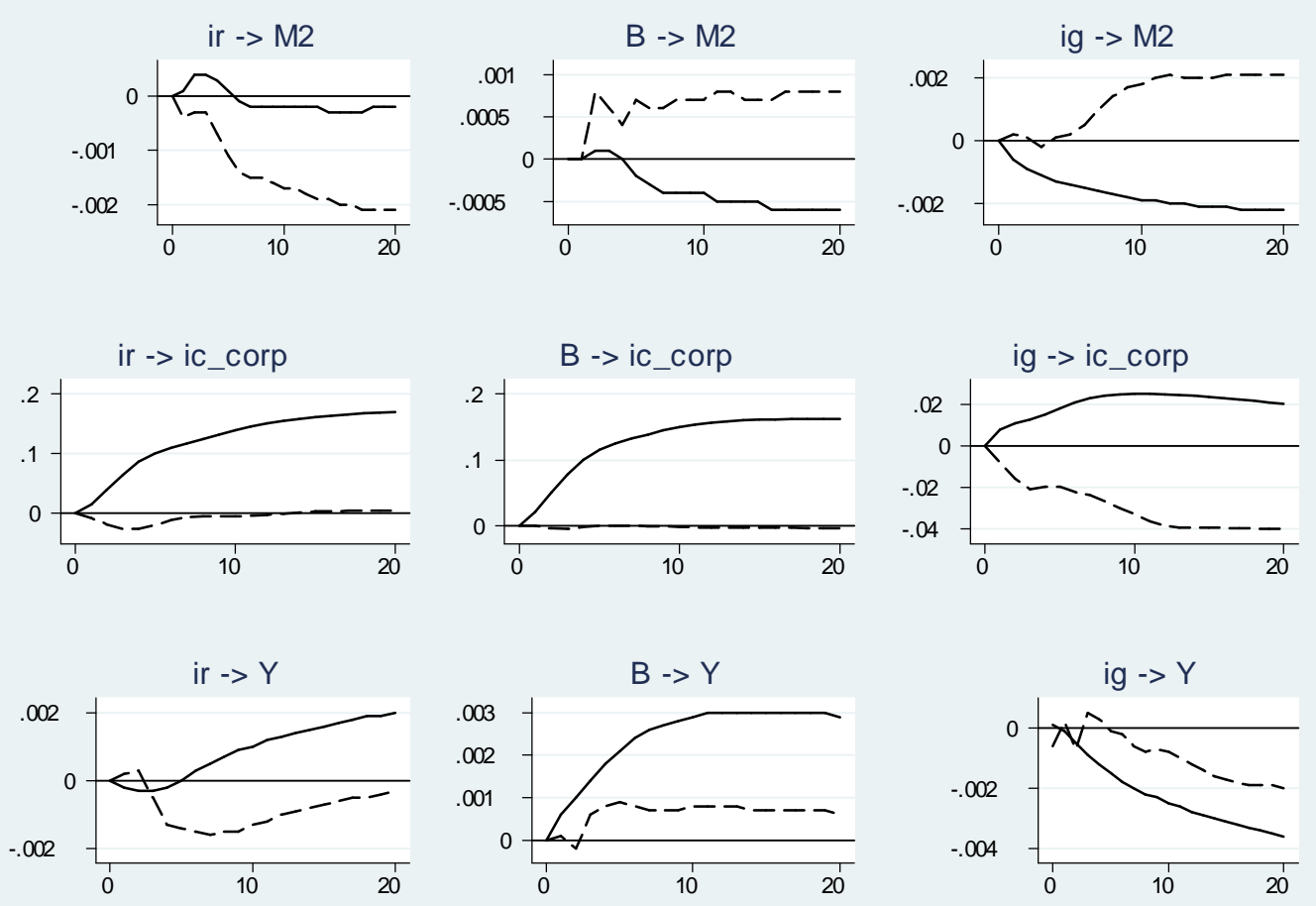

Figure 6: Impulse response functions for the United States. Corporate credit interest rate. Before (solid) and after (dashed) the break. 

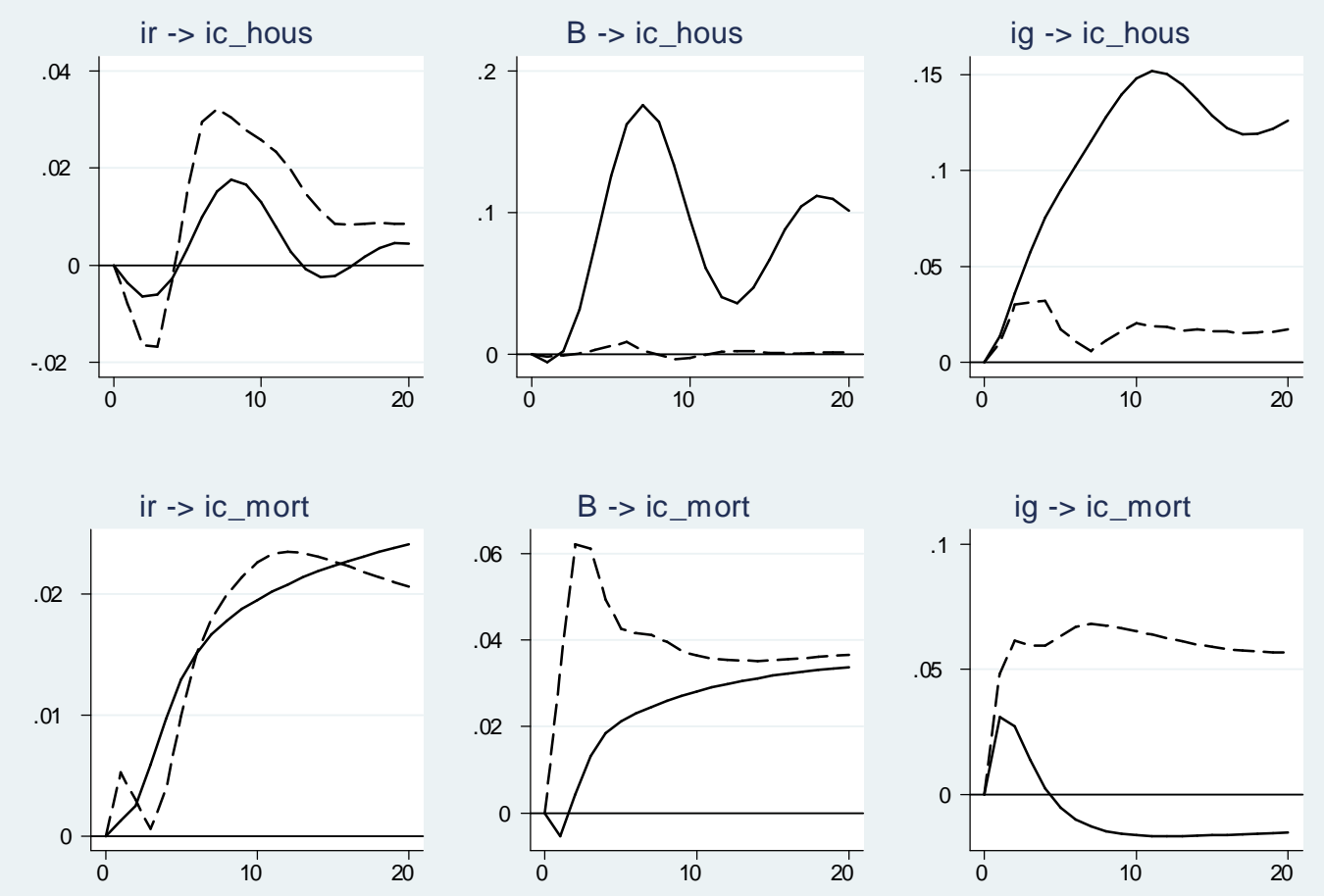

Figure 7: Impulse response functions for the United States. Credit interest rates to households. Before (solid) and after (dashed) the break. 